\title{
Accelerated Height Growth Versus Mortality of Quercus petraea (Matt.) Liebl. in Hungary
}

\author{
Krisztina Gulyás ${ }^{1 *}$, Norbert Móricz², Ervin Rasztovits², Adrienn Horváth³ ${ }^{3}$, Pál Balázs ${ }^{3}$, Imre Berki $^{3 *}$
}

(1) North-Hungarian District Water Directorate, Vörösmarty M. 77., H-3530 Miskolc, Hungary; (2) Hungarian Forest Research Institute (ERTI), Department of Ecology, Várkerület 30/A, H-9600 Sárvár, Hungary; (3) University of Sopron, Faculty of Forestry, Institute of Environmental and Earth Sciences, Bajcsy-Zsilinszky 4., H-9400 Sopron, Hungary

* Correspondence: e-mail: gulyas.krisztina@emvizig.hu
Citation: GULYÁS K, MÓRICZ N, RASZTOVITS E, HORVÁTH A, BALÁZS P, BERKI I 2019 Accelerated Height Growth Versus Mortality of Quercus petraea (Matt.) Liebl. in Hungary. South-east Eur for 10 (1): 1-7. DOI: https://doi.org/10.15177/ seefor.19-01

Received: 20 Nov 2018; Revised: 20 Jan 2019; Accepted: 25 Jan 2019; Published online: 27 Feb 2019

\begin{abstract}
Background and Purpose: Due to climate change, it is important to know to what extent forests will be impacted by atmospheric changes. This study focuses on the height growth response of sessile oak (Quercus petraea (Matt.) Liebl.) to counteracting effects of fostering and interfering changes under contrasting climatic conditions with special attention to the xeric limit zone of this species.

Materials and Methods: Twenty-eight sites were selected along a climatic gradient from the humid region in southwest Hungary to the continental-semiarid region in northeast Hungary where neighbouring old and young sessile oak stands were available for pair-wise comparison of height growth. While these young stands developed entirely in the significantly changed atmospheric conditions, the older trees lived only a part of their life time in such changed environment. The Ellenberg quotient (EQ) was used for describing climate aridity. Stand top height in each pair of old and young stands was measured to calculate the relative stand top height using yield tables of sessile oak for Hungary. Additionally, stand densities of old stands were measured. To demonstrate the height growth differences of old and young stands their relative stand top heights were compared as functions of EQ and stand density.

Results: The relative top heights of the young stands were significantly higher than of the older stands, which means that the overall growing conditions were better in the last 30-35 years due to atmospheric changes than the mean conditions during the lifetime of old stands. Although extreme drought events associated with climate change caused reduced stand density due to periodic tree mortality at the xeric limit of sessile oak, the synergetic effect of all atmospheric changes was still sufficient enough to accelerate height growth.

Conclusions: There has been an acceleration of height growth during the last decades despite the increased frequency of droughts. It cannot be concluded that height growth acceleration will continue in the future since climate models show an increasing tendency of dry extremes in Hungary that may overrule the positive fostering effect of atmospheric changes.
\end{abstract}

Keywords: Quercus petraea (Matt.) Liebl., height growth, climate change, xeric limit, stand density, stand top height

\section{INTRODUCTION}

Multi-year drought periods since the beginning of the 1980 s led to prolonged water deficits during the growing seasons in the Carpathian Basin [1, 2].

Droughts negatively influence the radial growth of trees $[3,4]$, reduce the vitality of trees [5], increase pest and disease invasions [6], and may lead to mortality [7], resulting in reduced stand density primarily at their xeric distributional limit [8].
Nevertheless, some studies suggest that forests may benefit from higher temperatures due to various compensating effects, such as fertilization through rising atmospheric $\mathrm{CO}_{2}$ concentration and nitrogen deposition, or improving water use efficiency [9-11]. Data of the ICP Forests plot showed a positive relationship between higher temperature, $\mathrm{CO}_{2}$ and $\mathrm{N}$ deposition, and the increase of volume increment [12]. The results of the project called RECOGNITION (Relationships Between Recent Changes of Growth and Nutrition of Norway 
Spruce, Scots Pine and European Beech Forests in Europe) showed that there were significant increases in height growth rates in many parts of Northern Europe. Increasing growth rates were also reported in many forests in Hungary [13] and even beyond its natural range, which is probably related to the changing environments $[14,15]$.

Sessile oak (Quercus petraea (Matt.) Liebl.) forests are among the most important forest communities in the Carpathian Basin and one of the economically most important tree species in Hungary. The distributional area of the species extends from the most humid to arid areas in Hungary. Since the early 1980s, severe drought periods have triggered several mortality events of sessile oak $[16,17]$, especially in the northeastern part of the country. Therefore, it is a wellsuited tree species for the analysis of the climatic background of decline and growth acceleration [18].

The largest $20 \%$ of trees, or a fixed number of 100 or 200 of the largest trees from the collective are called stand top height [11]. Among numerous dendrometrical parameters, stand top height is considered to be the most indicative factor for the stand's productivity $[11,19]$ which is less dependent on stand density and thinning [11]. Moreover, height growth is suitable for examining the effect of climate change [20].

The rate of tree height growth can be most precisely determined by measuring the trees of experimental stands in the frame of a long-term forest yield monitoring. In doing so, the growth rate of the same trees in time can be compared with the growth rate of the specified age found in the yield tables of sessile oak [21].

Any plots of the long-term forest yield monitoring near the xeric limit of sessile oak were affected by tree mortality during the last decades. Therefore, the growth of the same tree stock could not be analysed, but instead the current height of neighbouring old and young stands was compared. This way, we did not try to determine the exact quantity, but the direction of the change in height growth.

The comparison of the height growth performance of neighbouring old and young stands grown on the same site conditions enables the understanding of how the changing climate, the fertilization effect of the $\mathrm{CO}_{2}$-enriched atmosphere and nitrogen deposition influenced the height growth of trees. Since climate change became more rapid in the 1980s, the growth of young (30-35 years old) stands reflects the effect of atmospheric changes to a great extent. While these young stands developed entirely in the changed atmospheric conditions, the older trees lived only a part of their lifetime (with slower growth potential) in this changed environment. Consequently, the growth of the neighbouring old stands could serve as a comparison of the growth of young stands.

In this approach 28 stands along a climatic gradient were examined using a pair-wise comparison of the height growth of neighbouring old and young stands.

Our research questions were the following:

1) Has the height growth of sessile oak been accelerated or slowed down due to the counteracting effects of fostering and interfering atmospheric changes?

2) Is there a difference in height growth between the humid and more arid areas during the last three decades?

3) Is the height growth suppressed at the xeric limit of sessile oak, where frequent drought periods triggered mortality in the last decades?

\section{MATERIALS AND METHODS}

\section{Study Area}

The investigated 28 sessile oak sites are situated along the climatic gradient from the humid region in southwest Hungary to the continental-semiarid region in northeast Hungary (Figure 1).

The sites where neighbouring old ( $>50$ old years) and young ( $<50$ old years) stands were available for the pairwise comparison of growth were selected. The mean age difference of the old and young stands was 61 years. The site

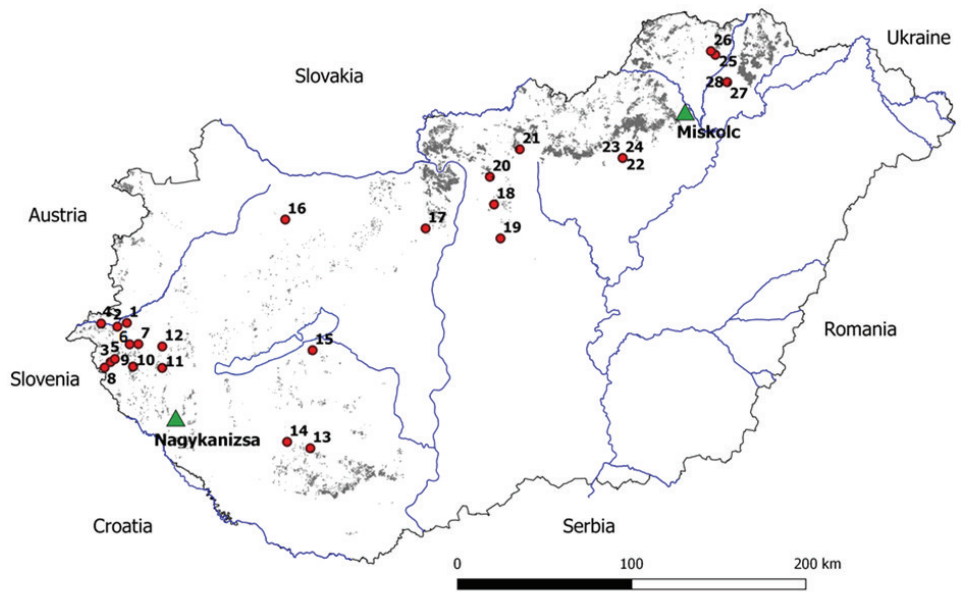

FIGURE 1. Selected sessile oak stands (circles), meteorological stations (triangles) and the distribution of sessile oak (grey) in Hungary. 
conditions of the neighbouring stands could be considered similar. All selected stands are in zonal position with low topographic variability, and are situated on deep loamy soils (Table 1).

In Hungary there has been a gradual change from oceanic to continental influence on the climate which is modified by a mediterreanen effect towards the southwest part of the country. This is reflected, for example, in the difference of summer precipitation sums by comparing the meteorological data of two official stations located in the Southwest (Nagykanizsa) and Northeast (Miskolc) of Hungary (Figure 1). A clear warming trend $\left(0.46-0.52^{\circ} \mathrm{C} /\right.$ decade) during the last three decades can be observed for summer temperatures, whereas contrasting trends $(-4.3 \mathrm{~mm} /$ decade for Nagykanizsa and $+18.8 \mathrm{~mm} /$ decade for Miskolc) are visible in the amount of summer precipitation (Figure 2 ).

\section{Meteorological Data}

To analyse the response of growth to climate change, the annual gridded data of the Ellenberg quotient (EQ) were obtained from the CARPATCLIM Database [22] for the period 1961-2010. The EQ has a good potential for describing the aridity limitation of forest stands in Hungary [23] and was thus used to describe the climate of the selected sites with a spatial resolution of $10 \mathrm{~km}$ (Equation 1, [24]).

$$
E Q=\frac{T_{\text {july }}}{P_{\text {anual }}}
$$

where $\mathrm{T}_{\text {july }}$ is mean temperature of July, and $\mathrm{P}_{\text {annual }}$ is annual precipitation sum.

TABLE 1. Site and stand characteristics.

\begin{tabular}{|c|c|c|c|c|c|c|c|c|c|}
\hline \multirow{2}{*}{$\begin{array}{l}\text { Stand } \\
\text { No. }\end{array}$} & \multirow{2}{*}{$\begin{array}{l}\text { Ellenberg } \\
\text { quotient } \\
\text { (EQ) }\end{array}$} & \multirow[b]{2}{*}{ Soil type } & \multicolumn{4}{|c|}{ Old stand } & \multicolumn{3}{|c|}{ Young stand } \\
\hline & & & $\begin{array}{c}\text { Age } \\
\text { (years) }\end{array}$ & $\begin{array}{c}\text { Top height } \\
\text { (m) }\end{array}$ & $\begin{array}{c}\text { Relative top } \\
\text { height (\%) }\end{array}$ & $\begin{array}{c}\text { Relative stand } \\
\text { density }(\%)\end{array}$ & $\begin{array}{c}\text { Age } \\
\text { (years) }\end{array}$ & $\begin{array}{c}\text { Top height } \\
\text { (m) }\end{array}$ & $\begin{array}{c}\text { Relative top } \\
\text { height (\%) }\end{array}$ \\
\hline 1 & 28 & Gleyic Luvisol & 109 & 31.5 & 118 & 94 & 26 & 13.5 & 126 \\
\hline 2 & 27.8 & Gleyic Luvisol & 62 & 23.1 & 109 & 90 & 25 & 13.6 & 132 \\
\hline 3 & 26.9 & Gleyic Luvisol & 94 & 29.1 & 114 & 95 & 27 & 14.7 & 132 \\
\hline 4 & 27.6 & Gleyic Luvisol & 122 & 30.6 & 114 & 92 & 32 & 16 & 122 \\
\hline 5 & 27.2 & Gleyic Luvisol & 104 & 32.4 & 123 & 85 & 31 & 14.9 & 117 \\
\hline 6 & 26.1 & Gleyic Luvisol & 94 & 31.8 & 125 & 92 & 28 & 15.5 & 135 \\
\hline 7 & 26.1 & Cutanic Luvisol & 93 & 31.3 & 123 & 84 & 35 & 19.3 & 137 \\
\hline 8 & 28 & Cutanic Luvisol & 99 & 31.7 & 122 & 94 & 26 & 15.8 & 148 \\
\hline 9 & 27 & Cutanic Luvisol & 126 & 35.4 & 129 & 98 & 31 & 17.5 & 138 \\
\hline 10 & 26.8 & Cutanic Luvisol & 125 & 34.7 & 127 & 101 & 26 & 15.7 & 147 \\
\hline 11 & 26.4 & Cutanic Luvisol & 114 & 35.5 & 132 & 105 & 30 & 18.5 & 150 \\
\hline 12 & 29.6 & Cutanic Luvisol & 115 & 34.6 & 128 & 81 & 32 & 15.5 & 119 \\
\hline 13 & 28.6 & Cutanic Luvisol & 101 & 31.9 & 122 & 89 & 25 & 16.7 & 162 \\
\hline 14 & 29 & Cutanic Luvisol & 51 & 25 & 133 & 90 & 26 & 17 & 159 \\
\hline 15 & 31.9 & Cambisol (Humic) & 79 & 24.3 & 102 & 69 & 45 & 18.3 & 106 \\
\hline 16 & 30.3 & Cambisol (Humic) & 96 & 26.3 & 102 & 98 & 25 & 12.8 & 124 \\
\hline 17 & 35.8 & Cambisol (Humic) & 98 & 22.4 & 87 & 73 & 46 & 17.4 & 99 \\
\hline 18 & 34.9 & Cambisol (Humic) & 116 & 26.2 & 97 & 68 & 25 & 12.6 & 122 \\
\hline 21 & 32.5 & Cambisol (Humic) & 70 & 22.7 & 101 & 77 & 25 & 12.7 & 123 \\
\hline 22 & 36.2 & Luvic Chernozem & 60 & 18.7 & 90 & 65 & 34 & 13.1 & 95 \\
\hline 23 & 36.6 & Luvic Chernozem & 98 & 16.6 & 64 & 62 & 33 & 12.9 & 96 \\
\hline 24 & 31.8 & Luvic Chernozem & 105 & 22.6 & 86 & 80 & 31 & 12.5 & 98 \\
\hline 25 & 34.1 & Luvic Chernozem & 64 & 23 & 107 & 83 & 29 & 15.8 & 133 \\
\hline 26 & 34.3 & Luvic Chernozem & 67 & 20.5 & 93 & 89 & 29 & 15.5 & 130 \\
\hline 27 & 38 & Luvic Chernozem & 77 & 18.4 & 78 & 71 & 26 & 12.4 & 112 \\
\hline 28 & 37 & Luvic Chernozem & 71 & 19.9 & 88 & 75 & 41 & 16.3 & 102 \\
\hline
\end{tabular}



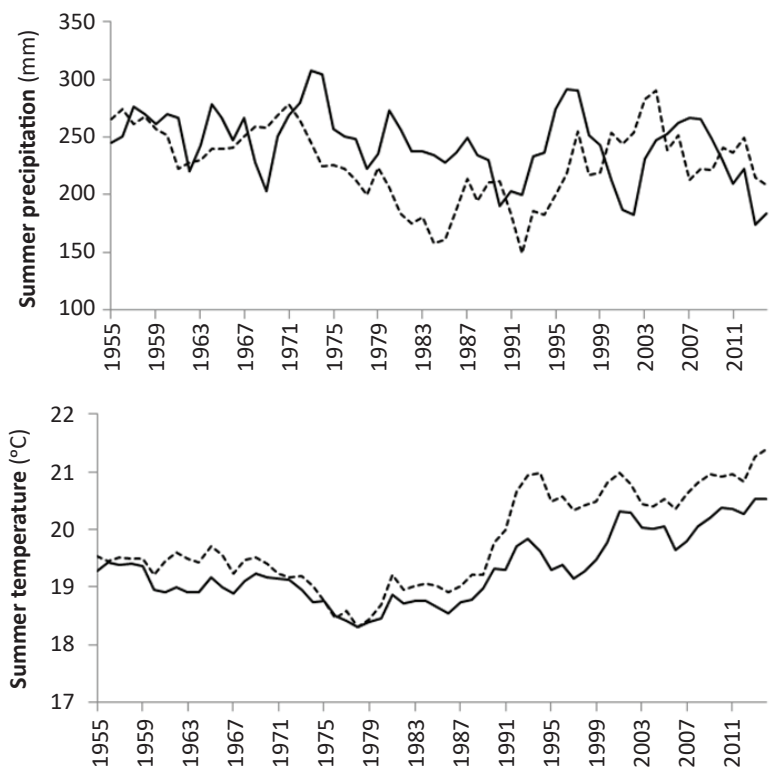

FIGURE 2. Trends in summer (J-J-A) precipitation and temperature for Nagykanizsa (solid line) and Miskolc (dotted line) meteorological stations for 1955-2016; curves are smoothed by 5-years moving average.

Topographical differences may cause differences in micro-climate conditions between the gridded data and the study sites. For that reason, special care was paid to select flat, zonal sites that might help to reduce the bias.

\section{Stand Height Analysis}

In each pair of old and young stands stand top height was measured to calculate the relative stand top height using the yield tables of sessile oak in Hungary [21].

The height of the visually highest 25 trees of each stand was measured using a TruPulse 200 laser instrument (Laser Technology, Inc., Colorado 80112 USA), after which the stand top height was considered as the mean value of the highest eight trees. Relative stand top height was calculated as the ratio of the current stand top height and the age-dependent height value of the average yield class (III). This refers to the overall height growth performance of the stands up to the given age [25]. To illustrate the height growth differences of the old and young stands their relative stand top heights were compared as functions of the EQ. To test if the stand top height values differ a one-way t-test was used. Additionally, the ratio of relative top heights was presented to show the differences of height growths of the young and old stands.

\section{Relative Stand Density}

Current stand density (trees $\cdot \mathrm{ha}^{-1}$ ) was estimated for old stands, after which relative stand density (Equation 2, [8]) was calculated to evaluate forest decline as a function of the $\mathrm{EQ}$ :

$$
D_{\text {rel\% }}=\left(\frac{D_{c u}}{D_{f u}}\right)
$$

where: $D_{\text {rel\% }}$ is relative stand density, $D_{c u}$ is current stand density, and $D_{f u}$ is fully stocked density (depending on the average stand diameter).

\section{RESULTS AND DISCUSSIONS}

Using the average yield class (III) of sessile oak as a referen-ce allowed the analysis of the effect of climate change on the relative stand top heights which are decreasing with increasing aridity, i.e. higher Ellenberg quotient (Figure 3).

While the highest stand top heights are charateristic on areas where the climate is humid and the soil conditions are the most favourable $(E Q<30)$, the lowest top heights can be found in the driest sites (EQ>35) where moisture availability limits growth. Interestingly, the top heights are lower in more humid areas $(E Q<29)$ due to less favourable soil conditions (Gleyic Luvisol) (Table 1).

The pair-wise comparison of the results showed that the relative top heights of the young stands were significantly higher than of the older stands $(t=7.04, p<0.01)$, which means that the overall growing conditions were better in the last 30 35 years than the mean conditions during the lifetime of the old stands (Figure 3 ). The ratio of relative stand heights of the young and old stands were above unity in 26 stands with a mean value of 1.15 (Figure 4).

Surprisingly, the height growth of sessile oak has accelera-ted even towards the dry sites. Furthermore, the young stands have an increasing growing tendency (around $+15 \%$ compared to the old stands). Since the growth of the old stands used as a reference has probably increased in the last decades, the real increase in the height of the young stand is higher than $15 \%$ as well.

According to our results, the height growth was accelerated even in dry regions although there was significant mortality (mainly middle-aged and old stands) in these regions due to extreme droughts during the last decades [8]. In a recent study (for further details see [18]) we have already determined the relative stand density for 17 old 


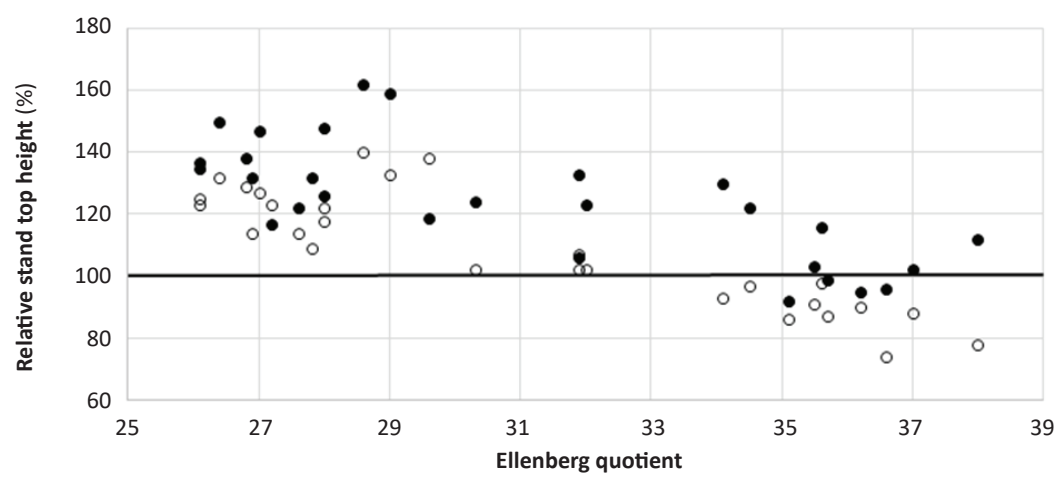

FIGURE 3. Relative stand top height of old (white circles) and young (black circles) stands as a function of Ellenberg quotient.

stands of this present study. We completed the available data with the measurement of the relative stand density in the missing 11 sites applying the same methodology. The comparison of the relative density and relative top height of the stands revealed that a significant difference of the relative stand density of sessile oak has emerged between humid and dry sites (Figure 5).
As a result of forest decline in dry sites, the relative density reduced to $60-70 \%$, while it remained at about $90 \%$ in humid regions. The parallel processes of declining relative stand density and accelareted height growth in dry sites are seemingly contradictory but not implausible progressions in forest ecosystems.

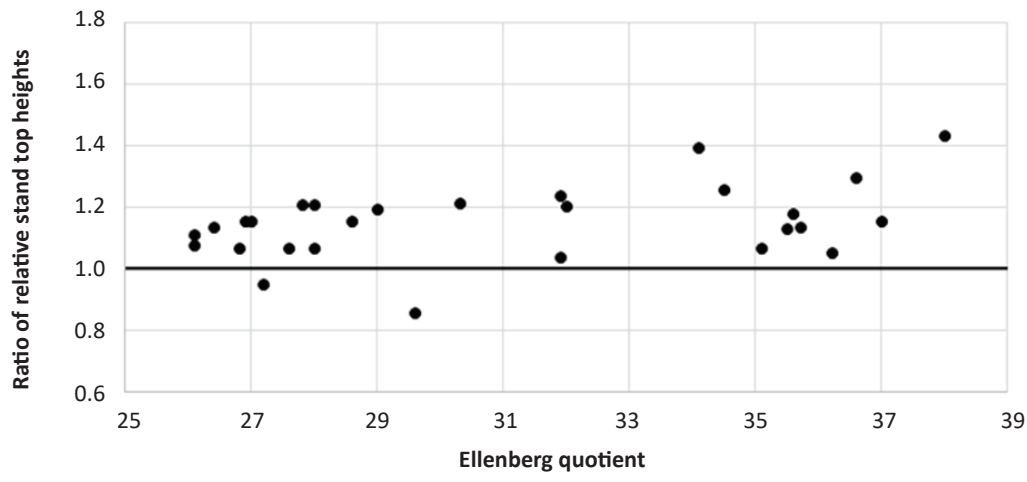

FIGURE 4. The ratio of relative top heights of young and old stands as a function of Ellenberg quotient.

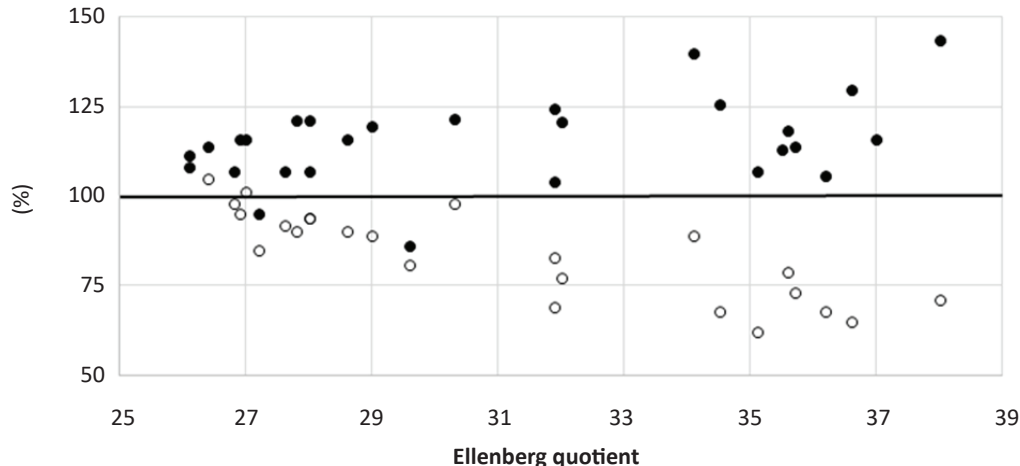

FIGURE 5. The ratio (in \%) of relative top heights of young and old stands (black circles) and relative stand density of old stands (white circles) as a function of Ellenberg quotient. 


\section{CONCLUSIONS}

Although extreme drought events associated with climate change caused periodic mortality at the xeric distributional limit of sessile oak, the effects of all atmospheric changes generated accelerate height growth.

Furthermore, our results do not support the fact that the excess nitrogen deposition fosters growth of trees primarily and only on low nitrogenous soil with sufficient water supply [11], since the height growth of trees on nitrogenous soil in humid climate is not greater than that of on humus-rich soils in drier climate.
Although there was an acceleration of growth in the last decades despite the increased frequency of droughts, this does not mean that growth acceleration will continue to be characteristic in the future since climate models show an increasing tendency of dry extremes in Hungary [26] which may overrule the positive effect of atmospheric changes.

\section{Acknowledgments}

This article was made in the frame of "EFOP-3.6.1-16-201600018 - Improving the role of research+development+innovation in the higher education through institutional developments assisting intelligent specialization in Sopron and Szombathely".

\section{REFERENCES}

1. SPINONI J, ANTOFIE T, BARBOSA P, BIHARI Z, LAKATOS M, SZALAI S, SZENTIMREY T, VOGT J 2013 An overview of drought events in the Carpathian Region in 1961-2010. Adv Sci Res 10 (1): 21-32. DOI: https://doi.org/10.5194/asr10-21-2013

2. BARTHOLY J, PONGRÁCZ R, PIECZKA I 2014 How the climate will change in this century? Hung Geogr Bull 63 (1): 55-67. DOI: https://doi.org/10.15201/hungeobull.63.1.5

3. BIGLER C, BRÄKER OU, BUGMANN $H$, DOBBERTIN $M$, RIGLING A 2006 Drought as incinting mortality factor in Scots Pine stands of the Valais, Switzerland. Ecosystems 9 (3): 330-343. DOI: https://doi.org/10.1007/s100210050126-2

4. BERTINI G, AMORIELLO T, FABBIO G, PIOVOSI M 2011 Forest growth and climate change: evidences from the ICPForests intensive monitoring in Italy. iForest 4: 262-267. DOI: https://doi.org/10.3832/ifor0596-004

5. MARTÍNEZ-VILALTA J, PINOL J 2002 Drough-induced mortality and hydraulic architecture in pine populations of the NE Iberian Peninsula. For Ecol Manage 161 (1-3): 247256. DOI: https://doi.org/10.1016/S0378-1127(01)00495$\underline{9}$

6. KOLB TE, FETTIG CJ, AYRES AP, BENTZ BJ, HICKE JA, MATHIASEN R, STEWART JE, WEED AS 2016 Observed and anticipated impacts of drought on forest insects and diseases in the United States. For Ecol Manage 380: 321 334. DOI: https://doi.org/10.1016/i.foreco.2016.04.051

7. Choat $B, B R O D R I B B$ TJ, BRODERSEN CR, DUURSMA RA, LÓPEZ R, MEDLYN BE 2018 Triggers of tree mortality under drought. Nature 558: 531-539. DOI: https://doi. org/10.1038/s41586-018-0240-x

8. BERKI I, RASZTOVITS E, MÓRICZ N, KOLOZS L 2016 The Role of Tree Mortality in Vitality Assessment of Sessile Oak Forests. South-east Eur for 7 (2): 91-97. DOI: https://doi. org/10.15177/seefor.16-14

9. ZHU Z, PIAO S, MYNENI RB, HUANG M, ZEMG Z, CANADELL JG, CIAIS P, SITCH S, FRIEDLINGSTEIN P, ARNETH A 2016 Greening of the Earth and its drivers. Nat Clim Change 6: 791-795. DOI: https://doi.org/10.1038/ $\underline{\text { nclimate3004 }}$

10. BOISVENUE C, RUNNING SW 2006 Impacts of climate change on natural forest productivity-evidence since the middle of the 20th century. Glob Change Biol 12 (5): 862-882. DOI: https://doi.org/10.1111/i.13652486.2006.01134.x

11. PRETZSCH H 2009 Forest dynamics, growth and yield. From measurement to model. Spinger-Verlag Berlin Heidelberg, $664 \mathrm{p}$
12. VRIES W, DOBBERTIN MH, SOLBERG S, VAN DOBBEN HF, SCHAUB M 2014 Impacts of acid deposition, ozone exposure and weather conditions on forest ecosystems in Europe: an overview. Plant and Soil 380 (1-2): 1-45. DOI: https://doi.org/10.1007/s11104-014-2056-2

13. SOMOGYI Z 2009 Some relationships of climate, climate change and tree growth (in Hungarian with English summary). "Klíma-21" Füzetek 56: 48-56

14. PERKINS D, UHL E, BIBER P, TOIT BD, CARRARO V, RÖTZER T, PRETZSH H 2018 Impact of climate trends and drought events on the growth of oaks (Quercus robur $L$. and Quercus petraea (Matt.) Liebl.) within and beyond their natural range. Forests 9 (3): 108. DOI: https://doi. org/10.3390/f9030108

15. SZABADOS I 2007 Effect of weather fluctuation on production, based on dendrochronological analysis (in Hungarian with English summary). In: Mátyás Cs, Vig $\mathrm{P}$ (eds) Erdő és klíma V., University of West Hungary, Sopron, Hungary, pp 295-306

16. JAKUCS 1988 Ecological approach to forest decay in Hungary. Ambio 17 (4): 267-274

17. VAJNA L 1990 Fungi associated with oak-decline. EPPO Bulletin 20: 3

18. MÁTYÁS C, BERKI I, BIDLÓ A, CSÓKA G, CZIMBER K, FÜHRER E, GÁLOS B, GRIBOVSZKI Z, ILLÉS G, HIRKA A, SOMOGYI Z 2018 Sustainability of Forest Cover under Climate Change on the Temperate-Continental Xeric Limits. Forests 9 (8): 489. DOI: https://doi.org/10.3390/f9080489

19. SPIECKER H, MIELIKEINEN K, KÖHL M, SKOVSGAARD JP 1996 Growth trends of European forests. European Forest Institute, Research report 5, Springer, Heidelberg, $372 \mathrm{p}$

20. LIBIETE-ZALITE Z, JANSONS A 2012 Climate impacts on lodgepole pine (Pinus contorta var. latifolia height growth in Latvia. In: Augustaitis A, Bytnerowicz A, Paoletti E (eds) Abstracts and Programme Joint International Conference „Biological Reactions of Forests to Climate Change and Air Pollution" Kaunas, Lithuania, $42 \mathrm{p}$

21. BÉKY A 1981 Yield of seedling sessile oak stands (in Hungarian). Erdészeti kutatások 74: 309-320

22. SZALAI S, AUER I, HIEBL J, MILKOVICH J, RADIM T, STEPANEK P, ZAHRADNICEK P, BIHARI Z, et al. 2013 Climate of the Greater Carpathian Region. Final Technical Report. URL: www.carpatclim-eu.org

23. SALAMON-ALBERT É, LŐRINCZ P. PAULER G, BARTHA D, HORVÁTH F 2016 Drought Stress Distribution Responses of Continental Beech Forests at their Xeric Edge in Central Europe. Forests 7 (12): 298. DOI: https://doi.org/10.3390/ $\underline{\mathrm{f7} 120298}$ 
24. ELLENBERG H 1988 Vegetation ecology of central Europe. Cambridge University Press $4^{\text {th }}$ edition, New York, $731 \mathrm{p}$

25. BERKI I, MÓRICZ N, RASZTOVITS E, GULYÁS K, GARAMSZEGI B, HORVÁTH A, BALÁZS P, LAKATOS B 2018 Mortality and accelerating growth is sessile oak sites (in Hungarian with English summary). Erdészettudományi Közlemények 8 (1): 119-130. DOI: https://doi.org/10.17164/EK.2018.008
26. GÁLOS B, FÜHRER E, CZIMBER K, GULYÁS K, BIDLÓ A, HÄNSLER A, JACOB D, MÁTYÁS C 2015 Climatic threats determining future adaptive forest management - A case study of Zala County. Időjárás 119: 425-441 